\title{
Have Stock Markets across the Globe Been Kidnapped by the Covid-19 Pandemic?
}

\author{
Huaibing $\mathrm{Yu}^{1}$
}

\begin{abstract}
Based on data of 6 major developed stock markets, this paper provides empirical evidences about how stock markets across the globe behave during the Covid-19 global pandemic. Evidences show that the movements of most stock market indices were individually dependent on the development of the Covid19 pandemic in the corresponding countries during the pre-bottom period. However, this phenomenon largely faded away after stock markets bottomed out and entered into the recovery stage. Vector error correction model (VECM) confirms the cross-markets equilibrium during the Covid-19 pandemic and the majority of stock markets are expected to restore to new equilibriums relatively quickly if exogenous shocks are introduced in the future.
\end{abstract}

JEL classification numbers: G10, G15, G17

Keywords: Covid-19 Pandemic, Stock Market, Cointegration, Market Behavior, Market Impact

\section{Introduction}

Before the Covid-19 pandemic, the U.S. stock market has had the longest bull market in history for more than 10 years which started after the great recession in $2009^{2}$. The sudden emergence of the Covid19 pandemic has been significantly disrupting stock markets not only in the U.S. but also in various countries, sending major market indices into the bear market. However, although the pandemic is still developing across the world, we see that major stock markets have started bouncing back from the post Covid-19 bottoms ${ }^{3}$. This paper describes and provides empirical evidences about how major developed stock markets across the globe behave and react to this global pandemic. It tries to answer the following questions: Have stock markets been kidnapped by Covid-19? Are they freed? How do stock markets adjust with respect to this pandemic? What can we expect if stock markets receive exogenous shocks in the near future?

Previous literatures provide meaningful evidences about how a large-scale crisis or a financial shock would impact on the global stock markets. A number of literatures seem to be very informative. Masulis (1990), based on an ARCH model, shows that stock price volatility is able to spill over from NYSE to Tokyo and London stock markets. This evidence implies that if an exogenous shock, like Covid-19,

\footnotetext{
${ }^{1}$ Department of Finance, Insurance, Real Estate and Law, University of North Texas, USA.

${ }^{2}$ March $9^{\text {th }}, 2019$ was the 10-year anniversary of the bull market in U.S. which recovered from the 2009 financial crisis.

${ }^{3}$ By May 26, 2020, market indices of the 6 countries in the sample all have bounced back by more than $20 \%$ from the corresponding post Covid-19 bottom. By the commonly accepted definition, all of them have jumped out of the bear market.
} 
creates a high degree of market uncertainty, then the effect would be spreading out and impacting on stock markets across the globe. Bartram and Wang (2005) draw empirical evidences from simulated time series financial data to argue that contagion effect should be existing during financial crisis and act as a general power over financial markets. Chiang et al. (2007) argue that stock markets are highly correlated during the 1997 Asian financial crisis. Khan and Park (2009) confirm this by showing that during the Asian financial crisis stock markets of Thailand, Malaysia, Indonesia, Korea, and Philippines experience contagion effect with each other. The market co-movements are beyond of the macroeconomic fundamentals, suggesting that the Asian financial crisis has a universal impact on the stock markets with spillover effect. Hon et al. (2007) show that the collapse of the 2001 tech bubble in the U.S. causes higher degree of correlation among international stock markets. Moreover, by studying past five financial crises, Kenourgios et al. (2011) further support the argument that global stock markets tend to share the common "disturbance" and form co-movements. Guo et al. (2011) offer additional support for these literatures by providing cross-markets evidences from the 2009 financial crisis.

Several recent papers provide valuable references regarding to the impact caused by the Covid-19 pandemic. By studying the google trend synthetic index, Papadamou et al. (2020) show that the increased search for the Covid-19 pandemic has a direct effect on the stock markets' implied volatilities and an indirect effect on stock returns. The related evidences of the paper assert that the Covid-19 pandemic contributes to the amplified level of risk-aversion. Ahundjanov et al. (2020) investigate the relationship between the Google search queries for Covid-19 and the major market indices. Their empirical evidences find that the increase of the Covid-19 online search is significantly related to the greater cumulative decline of market indices. Based on the daily data of ten UK industrial sector groupings from January to May of 2020, Sherif, M. (2020) claims that there is a strong relationship between the Covid-19 pandemic and the performance of regular stock market indices but not for the Dow Jones faith-based index. The paper also shows that the performances of different sectors vary significantly.

These recent papers confirm that the Covid-19 pandemic should have impacts on the stock markets at least for the short term. However, these papers didn't particularly investigate the behaviors and the responses of the markets, as the information of the severity of the Covid-19 pandemic is continuously priced in by the markets. From time series econometric standpoint, this paper contributes to the current literatures by offering significant statistical evidences regarding the movement behaviors of major market indices across the globe under the influence of the Covid-19 pandemic. The evidences of this paper show that markets initially succumbed to the advent of the Covid-19 pandemic. However, most markets commenced to recover at time points which were well before the Covid-19 daily new cases reached to the highest level in the corresponding countries.

The format of the paper is as the following: Section 2 describes the data and the statistical methodology. Section 3.1 gives insightful analyses of market behaviors during the pandemic for 6 major developed markets. Based on statistical testing results and from the time series econometric standpoint, Section 3.2 is trying to answer the question: Have stock markets been kidnapped by Covid-19? Section 3.3 offers evidences from the vector error correction model (VECM) to show the cross-markets equilibrium during the Covid-19 pandemic. It also provides important statistical inferences about how stock markets will respond and restore new equilibriums should future exogenous shocks be observed. Section 4 concludes this research paper.

\section{Data and Methodology}

Index data of 6 developed stock markets were collected: U.S. (Dow), U.K. (FTSE100), Canada (S\&P/TSX), Japan (Nikkei), Australia (S\&P/ASX), and Germany (DAX). Daily market index data were obtained from financial data provider investing.com ${ }^{4}$. Daily Covid-19 data were obtained from Our Word

\footnotetext{
${ }^{4}$ Investing.com. https://www.investing.com/
} 
in Data Organization ${ }^{5}$. Data of each country cover from the date of the $1^{\text {st }}$ Covid-19 case reported in the country up to May 26, 2020.

To test the stationarity condition, augmented Dickey-Fuller unit root test (Dickey and Fuller, 1979; Hamilton, 1994) with 2 augmentation terms and a trend term is used ${ }^{6}$, as shown in equation (1)

$$
\Delta \mathrm{y}_{\mathrm{t}}=\alpha+\beta \mathrm{y}_{\mathrm{t}-1}+\delta \mathrm{t}+\Upsilon_{1} \Delta \mathrm{y}_{\mathrm{t}-1}+\Upsilon_{2} \Delta \mathrm{y}_{\mathrm{t}-2}
$$

Testing for cointegration follows Johansen trace test procedures. Equation (2) specifies a generic setup of the vector error correction model (VECM) (Johansen,1988, 1991, 1995; Lütkepohl, 2005; Watson, 1994). The matrix $\Pi$ can be written as $\Pi=\boldsymbol{\alpha} \times \boldsymbol{\beta}^{\prime}$, where $\boldsymbol{\alpha}$ is a matrix of adjustment coefficients and $\boldsymbol{\beta}^{\prime}$ is a matrix of cointegration coefficients. The proper number of lags in the VECM can be determined by resorting to Tsay (1984), Paulsen (1984), and Nielsen (2006).

$$
\Delta \mathrm{Z}_{\mathrm{t}}=\Gamma_{1} \Delta \mathrm{Z}_{\mathrm{t}-1}+\Gamma_{2} \Delta \mathrm{Z}_{\mathrm{t}-2}+\ldots+\Gamma_{\mathrm{P}-1} \Delta \mathrm{Z}_{\mathrm{t}-(\mathrm{P}-1)}+\Pi \mathrm{Z}_{\mathrm{t}-\mathrm{P}}+\varepsilon_{\mathrm{t}}
$$

\section{Empirical Results}

\subsection{How did stock markets behave after the corresponding $1^{\text {st }}$ Covid-19 case was introduced?}

As shown in Table 1, countries reported their $1^{\text {st }}$ Covid-19 cases in late January. Out of the 6 developed markets, Japan was the first country that the Covid-19 was introduced. While, U.K. was the last country that started to experience this pandemic. The time difference of the Covid-19 introduction between Japan and U.K. is only 16 days with other 4 countries in the middle, which shows the fast spread of the virus. After the introduction of the Covid-19, all 6 countries' stock markets began to experience huge sell-offs with market indices plummeting significantly. The average index loss of the 6 developed markets is $34.31 \%$ and the average bottoming period is 40.5 trading days. The shortest bottoming period is 37 trading days for U.K. and Germany, while the longest bottoming period is 45 trading days for Japan, though the difference is not very striking. By the time of this writing, the Covid-19 pandemic is still unfolding and it is reasonable to expect some ups and downs in the markets. However, the fast recovery of market indices gives a huge contrast to the 2009 financial crisis, in which the Dow lost more than 50\% over 17 months and took roughly 4 years to recover.

Table 1: Descriptive Information of Six Developed Equity Markets Across the Globe

\begin{tabular}{cccccccc}
\hline Country & Index & $\begin{array}{c}\text { Date of the } 1^{\text {st }} \\
\text { Reported } \\
\text { Covid-19 } \\
\text { Case }\end{array}$ & $\begin{array}{c}\text { Date of Index } \\
\text { Bottom }\end{array}$ & $\begin{array}{c}\text { Level and } \\
\text { Return of } \\
\text { Index at } \\
\text { Bottom }\end{array}$ & $\begin{array}{c}\text { Bottoming } \\
\text { Period (in td) }\end{array}$ & $\begin{array}{c}\text { Date of } \\
\text { Reported Daily } \\
\text { Covid-19 New } \\
\text { Cases Hit High }\end{array}$ & $\begin{array}{c}\text { Num } \\
\text { of }\end{array}$ \\
Obs \\
U.S. & Dow & Jan 21, 2020 & $\begin{array}{c}\text { March 23, } \\
2020\end{array}$ & $\begin{array}{c}18,591.93 \\
(-36.32 \%)\end{array}$ & 44 td & April 26, 2020 & 88 \\
U.K. & FTSE100 & Jan 31, 2020 & $\begin{array}{c}\text { March 23, } \\
2020\end{array}$ & $\begin{array}{c}4,993.89 \\
(-31.46 \%)\end{array}$ & 37 td & April 12, 2020 & 79 \\
Canada & S\&P/TSX & Jan 26, 2020 & $\begin{array}{c}\text { March 23, } \\
2020\end{array}$ & $\begin{array}{c}11,228.49 \\
(-35.63 \%)\end{array}$ & 40 td & May 4, 2020 & 84
\end{tabular}

\footnotetext{
${ }^{5}$ Our World in Data. https://ourworldindata.org/coronavirus-source-data

${ }^{6}$ Two augmentation terms (two lags) are specified to ensure errors are i.i.d. white noise.
} 


\begin{tabular}{|c|c|c|c|c|c|c|c|}
\hline Japan & Nikkei & Jan 15, 2020 & $\begin{array}{c}\text { March 19, } \\
2020\end{array}$ & $\begin{array}{l}16,552.83 \\
(-30.79 \%)\end{array}$ & $45 \mathrm{td}$ & April 12, 2020 & 88 \\
\hline Australia & S\&P/ASX & Jan 25, 2020 & $\begin{array}{c}\text { March 23, } \\
2020\end{array}$ & $\begin{array}{c}4,546.00 \\
(-35.00 \%)\end{array}$ & $40 \mathrm{td}$ & March 23, 2020 & 84 \\
\hline Germany & DAX & Jan 28, 2020 & $\begin{array}{c}\text { March 18, } \\
2020\end{array}$ & $\begin{array}{c}8,441.71 \\
(-36.64 \%)\end{array}$ & $37 \mathrm{td}$ & March 28, 2020 & 83 \\
\hline \multicolumn{8}{|c|}{$\begin{array}{l}\text { Note: data for each country covers from the date of the } 1^{\text {st }} \text { Covid- } 19 \text { case reported in the country up to May } 26,2020 \text {. "Date } \\
\text { of Index Bottom" is the date of the subsequent lowest index level after the Covid- } 19 \text { is introduced into the country. "td" } \\
\text { refers to "trading day". "Num of Obs" refers to the total number of observations for each market index. The return of the } \\
\text { index at bottom is the percentage change of the index level at the bottom and the index level when the } 1{ }^{\text {st }} \text { Covid- } 19 \text { case is } \\
\text { reported in the corresponding country. If the date of the } 11^{\text {st }} \text { Covid- } 19 \text { case reported in the country is not a trading day, then } \\
\text { the following trading day's index level is used for the calculation of the index return. }\end{array}$} \\
\hline
\end{tabular}

In the meantime, Table 1 yields very interesting evidences about the market recovery. It is the fact that all markets, except for Australia (S\&P/ASX) ${ }^{7}$, have fully bottomed out well before the daily reported Covid-19 new cases hit high in the corresponding countries. It sends us the implication that markets tend to lead the development of the pandemic and show signs of forward-looking self-recovery, though they were significantly negatively impacted by the Covid-19 pandemic in the early stage.

\subsection{Have stock markets been kidnapped by Covid-19?}

To answer this question, we need to construct a logic. A natural one would be: if a stock market is kidnapped by or succumbed to the force of the Covid-19, then the index movement should be dependent on the development of the pandemic and this relationship should be statistically significant. Based on the data of the sample, answers are provided in this section from the time series econometric standpoint.

In Figure 1, market index level is plotted against daily Covid-19 new cases (in negative form) for each country $^{8}$. Visually, in general, we are able to obtain the impression that, when the Covid-19 pandemic was worsening in each country in terms of daily reported new cases, the corresponding market index plummeted accordingly. Here, evidences also confirm that all market indices, expect for S\&P/ASX (Australia), bottomed out well in advance of the corresponding peak of daily Covid-19 new cases. Moreover, Figure 1 also exhibits that after each index bottom the recovery shape is largely similar across the 6 markets, though the pattern of daily Covid-19 new cases is varying notably by different countries.

Table 2 provides very interesting and important empirical evidences for the market behaviors under the pandemic. Using augmented Dickey-Fuller unit root test, each market index and country daily Covid19 new cases are tested for time series stationarity for both pre-bottom and post-bottom periods. As we can see, all market indices and country daily Covid-19 new cases are non-stationary with one unit root (I (1)) for both periods, meaning that both series are not mean-reverting and possess varying stochastic properties throughout time?

The important discoveries come from the cointegration tests between market indices and country daily Covid-19 new cases. From Table 2, we see 5 out of 6 market indices, except for Nikkei (Japan), established cointegration relations during the pre-bottom period ${ }^{10}$. This evidence indicates that after

\footnotetext{
${ }^{7}$ Interestingly, Australia is the only country that the market index bottom coincided with the date of the highest daily reported Covid-19 new cases.

${ }^{8}$ For each country, the daily Covid-19 new cases are in negative form. For example, if a country has a daily Covid19 new cases of 500, it is recorded as $-\mathbf{5 0 0}$. The way to model this is to draw important statistical inferences from the data.

${ }^{9} \mathrm{I}(1)$ is the necessary condition for the potential existence of cointegration between two time series.

${ }^{10}$ Cointegration relation is based on $99 \%$ significance level.
} 
Covid-19 was introduced respectively into the 5 countries the market indices were individually cointegrated with the corresponding country daily Covid-19 new cases ${ }^{11}$. A direct inference is that before the bottom the movements of market indices were individually dependent on the development of the Covid-19 pandemic in terms of daily new cases in corresponding countries ${ }^{12}$. However, the cointegration relations largely disappeared after stock markets bottomed out. Table 2 shows that 4 out of 6 market indices, except for S\&P/ASX (Australia) and DAX (Germany), have no individual cointegration relation with country daily Covid-19 new cases during the post-bottom period. This result supports the argument that for most stock markets the influence of Covid-19 largely faded away after markets hit the trough and moved into the recovery stage. This is also consistent with the logic that the Covid-19 pandemic will eventually diminish and the stock markets will be free from its shadow. In summary, for most countries in the sample, Covid-19 pandemic had overwhelming commanding power on the movements of market indices before the bottom. However, this commanding power tended to largely vanish when markets entered into the recovery stage.
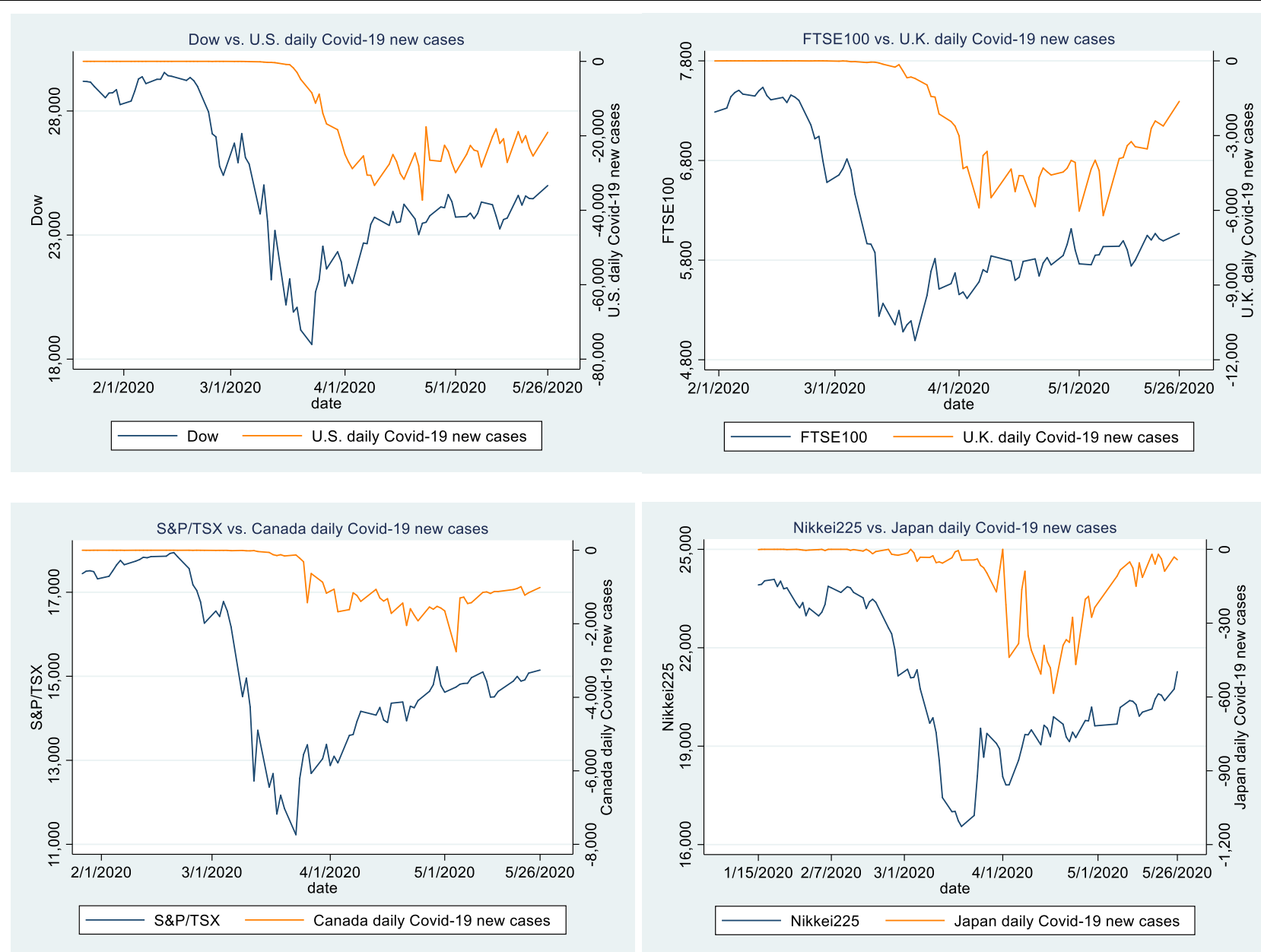

\footnotetext{
${ }^{11}$ Before the Covid-19 pandemic, statistically there cannot be existing cointegration relation between any market index and the country daily Covid-19 new cases which is zero.

${ }^{12}$ Figure 1 confirms and provides visual clue for this argument.
} 

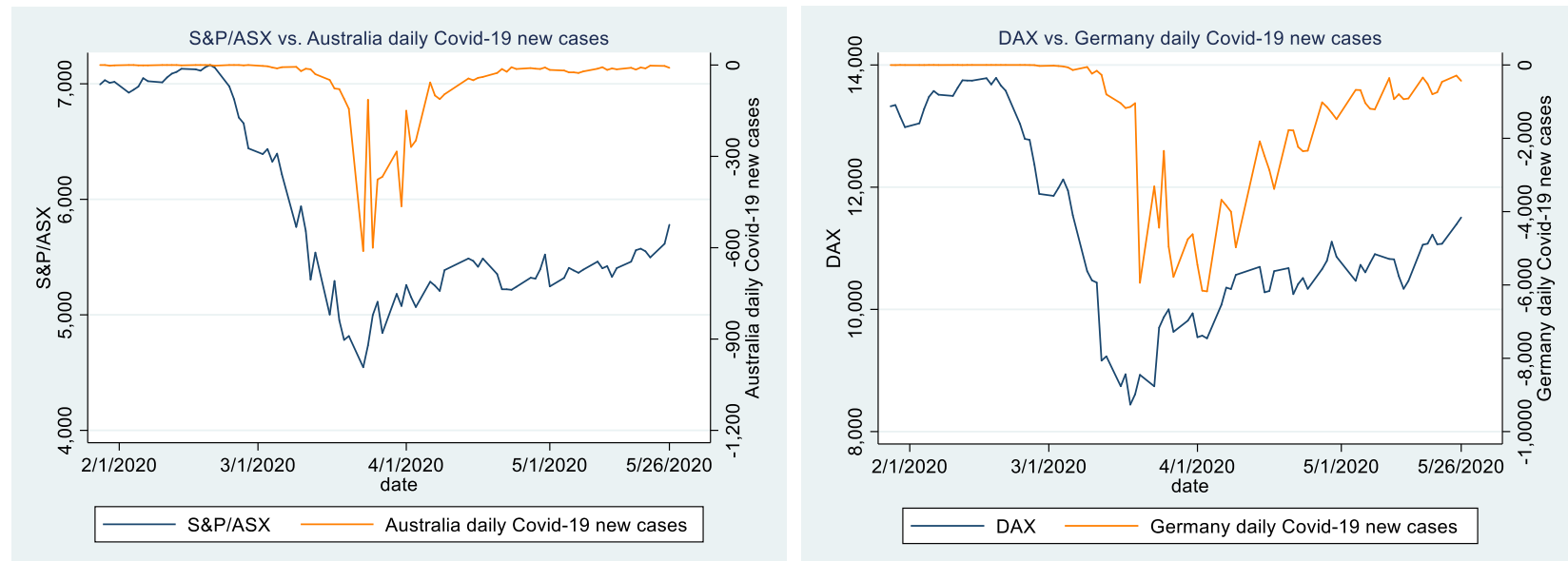

Figure 1: Time Series Plots of Index Level against Country Daily Covid-19 New Cases

Note: this figure shows time series plots of index levels against country daily Covid-19 new cases for 6 countries: U.S., U.K., Canada, Japan, Australia, and Germany. The starting data point of each time series is the date of the $1^{\text {st }}$ reported Covid-19 case in the corresponding country. If the date of the $1^{\text {st }}$ Covid-19 case reported in the country is not a trading day, then the starting data point would be the following trading day. The ending data point is May 26, 2020 for each time series. The daily Covid-19 new cases are in negative form.

Table 2: Stationarity and Cointegration of Market Indices and Country Covid-19 New Cases

\begin{tabular}{|c|c|c|c|c|c|}
\hline Country & $\begin{array}{l}\text { Market } \\
\text { Index }\end{array}$ & $\begin{array}{c}\text { Pre-Bottom } \\
\text { Stationarity } \\
\text { (Index | New } \\
\text { Cases) }\end{array}$ & $\begin{array}{c}\text { Pre-Bottom } \\
\text { Cointegration } \\
\text { (Yes/No|Rank) }\end{array}$ & $\begin{array}{l}\text { Post-Bottom } \\
\text { Stationarity } \\
\text { (Index | New } \\
\text { Cases) }\end{array}$ & $\begin{array}{c}\text { Post-Bottom } \\
\text { Cointegration } \\
\text { (Yes/No|Rank) }\end{array}$ \\
\hline U.S. & Dow & I (1) | I (1) & Yes | Rank (1) & I (1) | I (1) & No | Rank (0) \\
\hline U.K. & FTSE100 & $\mathrm{I}(1) \mid \mathrm{I}(1)$ & Yes | Rank (1) & I (1) | I (1) & No|Rank (0) \\
\hline Canada & S\&P/TSX & I (1) | I (1) & Yes | Rank (1) & I (1) | I (1) & No | Rank (0) \\
\hline Japan & Nikkei & I (1) | I (1) & No | Rank (0) & I (1) | I (1) & No | Rank (0) \\
\hline Australia & S\&P/ASX & I (1) | I (1) & Yes | Rank (1) & I (1) | I (1) & Yes | Rank (1) \\
\hline Germany & DAX & I (1) | I (1) & Yes | Rank (1) & $\mathrm{I}(1) \mid \mathrm{I}(1)$ & Yes | Rank (1) \\
\hline \multicolumn{6}{|c|}{$\begin{array}{l}\text { Note: Stationarity is determined by conducting augmented Dickey-Fuller unit root test with } 2 \text { lags and a } \\
\text { trend being specified. Cointegration relation is tested based on the vector error correction model (VECM) } \\
\text { and follows Johansen trace test procedures. The selection of lag order refers to the procedures by Tsay } \\
\text { (1984), Paulsen (1984), and Nielsen (2006). Rank (1) indicates } 1 \text { set of cointegration relation and Rank (0) } \\
\text { indicates no cointegration relation. All test results are based on 99\% significance level. }\end{array}$} \\
\hline
\end{tabular}




\subsection{The equilibrium of stock markets during the Covid-19 pandemic}

Although most market indices individually cointegrated with the development of the Covid-19 pandemic before they bottomed out from the trough, stock markets were cointegrated with each other for the entire sample period after the Covid-19 was introduced into each country ${ }^{13}$. Figure 2 shows that during the pandemic 6 market indices were moving coherently for both the periods of declining and recovery ${ }^{14}$. Table 3 provides the results of vector error correction model (VECM) to show how markets would behave toward the equilibrium among them. The estimated adjustment coefficients of U.S. (Dow with -0.24), Canada (S\&P/TSX with -0.21), and Australia (S\&P/ASX with -0.20) are statistically significant and relatively large in absolute value, meaning that they are able to restore toward new equilibriums relatively quickly if future exogenous shocks are experienced. Japan (Nikkei with -0.14) also shows a significant behavior of restoring to new equilibriums with a sizable pace. However, countries such as U.K. (FTSE100 with -0.07) and Germany (DAX with -0.08) exhibit small estimated adjustment coefficients in absolute value, suggesting relatively slow speed of new equilibrium restoration. The results from the VECM implies that if a future exogenous shock is introduced, such as the invention of successful vaccines or therapeutics, stock markets of U.S., Canada, and Australia tend to react swiftly to form new equilibriums with the expectation of sending indices higher. Japan's stock market tends to follow up relatively quickly as well. Nevertheless, stock markets of U.K. and Germany may show reluctant behaviors of moving toward new equilibriums.

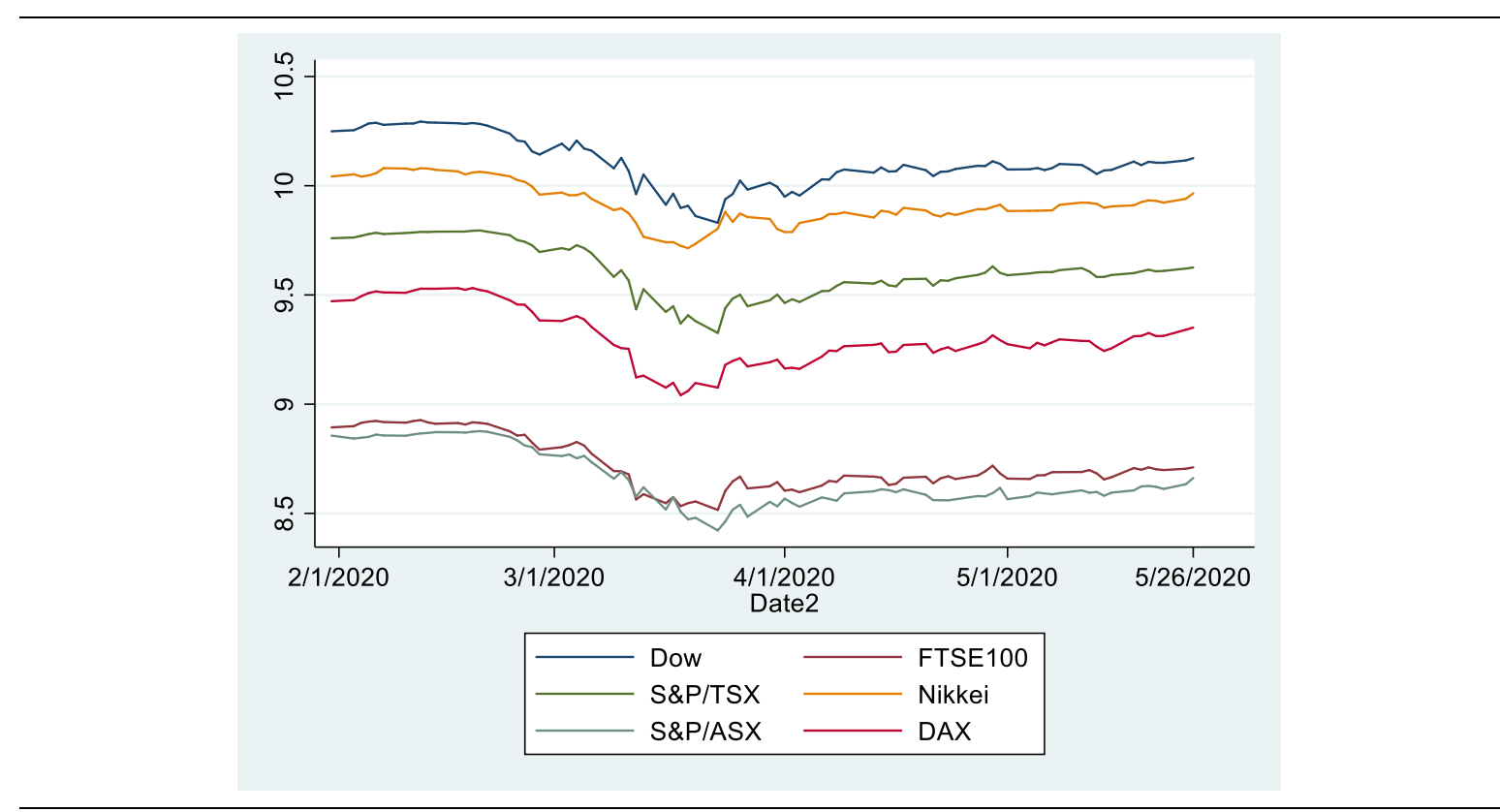

Figure 2: Time Series Plots of Six Major Market Indices Across the Globe

Note: this figure shows time series plots of 6 major market indices: U.S., U.K., Canada, Japan, Australia, and Germany. Market indices are in natural logarithm forms and cover a period from Jan 31, 2020 to May 26, 2020 in which all countries in the sample are experiencing the Covid-19 pandemic . Each market index is identified as I(1) by augmented Dickey-Fuller unit root tests with 2 lags and a trend being specified.

${ }^{13}$ U.K. was the last country that entered into the Covid-19 pandemic of which the date of the $1^{\text {st }}$ reported case is Jan 31, 2020. It means that from Jan 31, 2020 all 6 countries in the sample started to experience the pandemic.

Augmented Dickey-Fuller unit root tests are conducted for each market index with the result of each index being I (1). Cointegration tests confirm that 6 market indices are cointegrated with 1 cointegration relation for the period of Jan 31, 2020 to May 26, 2020.

${ }^{14}$ Market indices are in natural logarithm forms. 
Table 3: Vector Error Correction Model of Six Major Market Indices Across the Globe

\begin{tabular}{ccc}
\hline & Estimated Adjustment Coefficients & Estimated Cointegration Coefficients \\
\hline \multirow{2}{*}{ Dow } & $-0.24 * * *$ & 1 (normalized) \\
& $(-3.87)$ & -0.38 \\
FTSE100 & -0.07 & $(0.4738)$ \\
& $(-1.24)$ & $1.10 * * *$ \\
S\&P/TSX & $-0.21 * * *$ & $(3.37)$ \\
& $(-3.39)$ & $1.81 * * *$ \\
Nikkei & $-0.14 * * *$ & $(4.12)$ \\
& $(-3.27)$ & $1.08 * * *$ \\
S\&P/ASX & $-0.20 * * *$ & $(4.46)$ \\
& $(-3.98)$ & $-3.83 * * *$ \\
DAX & -0.08 & $(-6.68)$ \\
\hline
\end{tabular}

This table presents the results of the vector error correction model (VECM) of 6 major market indices based on the period of Jan 31, 2020 to May 26, 2020. Market indices are in natural logarithm forms. Augmented Dickey-Fuller unit root tests are conducted for each market index with the result of each index being I (1). Cointegration test confirms that 6 market indices are cointegrated with 1 cointegration relation. The model specifies 2 lags as referring to Tsay (1984), Paulsen (1984), and Nielsen (2006). Numbers in the parentheses are Z-statistics. “***”, “**”, and “**” denote significance at $99 \%$, 95\%, and 90\% respectively.

\section{Conclusion}

Based on data of 6 major developed stock markets, this paper provides empirical evidences about how stock markets across the globe behave during the Covid-19 global pandemic. Market indices plummeted significantly after the Covid-19 was introduced into corresponding countries. However, most of them bottomed out well before the peak of each country's daily Covid-19 new cases, with only 1 market index having a coincident manner. During the pre-bottom period, 5 out of 6 market indices individually established cointegration relations with the daily Covid-19 new cases of the corresponding countries, meaning that the movements of market indices were individually dependent on the development of the Covid-19 pandemic. However, these cointegration relations largely disappeared after stock markets bottomed out, with only 2 countries' market indices still being cointegrated. The evidences suggest that Covid-19 had a general commanding power on the movements of stock markets during the early stage of the pandemic, which largely faded away after markets started entering into the recovery stage. Results from the vector error correction model (VECM) show that stock markets tend to have co-movements during the Covid-19 pandemic and form cross-markets equilibrium. The majority of stock markets are also expected to restore to new equilibriums relatively quickly if exogenous shocks that related to Covid19 are introduced in the future. 


\section{References}

Ahundjanov, B. B., Akhundjanov, S. B. and Okhunjanov, B. B. (2020). Information Search and Financial Markets under COVID-19. Entropy, 22(7), 791.

Bartram, S.M. and Wang, Y.H. (2005). Another look at the relationship between cross-market correlation and volatility. Finance Research Letters, 2(2), pp.75-88.

Chiang, T.C., Jeon, B.N. and Li, H. (2007). Dynamic correlation analysis of financial contagion: Evidence from Asian markets. Journal of International Money and finance, 26(7), pp.1206-1228.

Dickey, D.A. and Fuller, W.A. (1979). Distribution of the estimators for autoregressive time series with a unit root. Journal of the American statistical association, 74(366a), pp.427-431.

Guo, F., Chen, C.R. and Huang, Y.S. (2011). Markets contagion during financial crisis: A regimeswitching approach. International Review of Economics \& Finance, 20(1), pp.95-109.

Hamao, Y., Masulis, R.W. and Ng, V. (1990). Correlations in price changes and volatility across international stock markets. The review of financial studies, 3(2), pp.281-307.

Hamilton, J. D. 1994. Time Series Analysis. Princeton University Press.

Hon, M.T., Strauss, J.K. and Yong, S.K. (2007). Deconstructing the Nasdaq bubble: A look at contagion across international stock markets. Journal of International Financial Markets, Institutions and Money, 17(3), pp.213-230.

Johansen, S. (1988). Statistical analysis of cointegration vectors. Journal of economic dynamics and control, 12(2-3), pp.231-254.

Johansen, S. (1991). Estimation and hypothesis testing of cointegration vectors in Gaussian vector autoregressive models. Econometrica: journal of the Econometric Society, pp.1551-1580.

Johansen, S. (1991). Estimation and hypothesis testing of cointegration vectors in Gaussian vector autoregressive models. Econometrica: journal of the Econometric Society, pp.1551-1580.

Johansen, S. (1995). Likelihood-based inference in cointegrated vector autoregressive models. Oxford University Press on Demand.

Kenourgios, D., Samitas, A. and Paltalidis, N. (2011). Financial crises and stock market contagion in a multivariate time-varying asymmetric framework. Journal of International Financial Markets, Institutions and Money, 21(1), pp.92-106.

Khan, S. and Park, K.W.K. (2009). Contagion in the stock markets: The Asian financial crisis revisited. Journal of Asian Economics, 20(5), pp.561-569.

Lütkepohl, H. (2005). New introduction to multiple time series analysis. Springer Science \& Business Media.

Nielsen, B. (2006). Order determination in general vector autoregressions. In Time series and related topics (pp. 93-112). Institute of Mathematical Statistics.

Papadamou, S., Fassas, A., Kenourgios, D. and Dimitriou, D. (2020). Direct and Indirect Effects of COVID-19 Pandemic on Implied Stock Market Volatility: Evidence from Panel Data Analysis. MPRA working paper.

Paulsen, J. (1984). Order determination of multivariate autoregressive time series with unit roots. Journal of time series analysis, 5(2), pp.115-127.

Sherif, M. (2020). The impact of Coronavirus (COVID-19) outbreak on faith-based investments: An original analysis. Journal of Behavioral and Experimental Finance, 100403.

Tsay, R.S. (1984). Order selection in nonstationary autoregressive models. The Annals of Statistics, 12(4), pp.1425-1433.

Watson, M.W. (1994). Vector autoregressions and cointegration. Handbook of econometrics, 4, pp.28432915. 